development of the Company in recent years and has been made necessary by the increasing num. bers of new and improved instruments developed by the Research Department. The building, which was designed by Edward D. Mills and Partners, architects, was completed in less than a year by the contractors, J. Jarvis and Sons, Ltd.

J. G. HAMMOND

\title{
LIFE AND ITS ENVIRONMENT IN ANCIENT SEAS
}

$\mathrm{D}$ URING the British Association meeting at Norwich, the Geology and Zoology Sections (C and D) held a joint session on "Life and its Environment in Ancient Seas".

Prof. C. M. Yonge, president of Section D, was in the chair and about 150 persons attended. The programme was designed as a general session covering a wide range of palæoecological topics, but unfortunately the opening address by Prof. Kaare Strøm (professor of limnology, University of Oslo), entitled, "In Quest of Ancient Seas", and the paper by Dr. R. H. Cummings (Department of Geology, University of Glasgow) on the "Polæoecology of Foraminifera in Reef Limestones" were both cancelled, and so the scope of the meeting was more restricted than originally planned.

The paper by Dr. K. A. Joysey (Department of Zoology, University of Cambridge) on "The Life of Cephalopods in Ancient Seas" was a discussion of existing views on the mode of life of fossil forms, considered in the light of new information about living cephalopods. Dr. Anna Bidder (Department of Zoology, Cambridge) showed a series of excellent colour slides of the living Nautilus and gave an account of her observations, largely based on freshly captured specimens living in the aquarium at Noumea, New Caledonia. The paper by Mr. R. W. Sheldon and Dr. F. M. Broadhurst (Department of Geology, University of Manchester) and Dr. J. G. Potts (United Steel Companies, Ltd.) on "Aspects of the Palæoecology of Marine Faunas in the Upper Carboniferous of the Southern Pennines", was a preliminary account of work still in progress seeking to elucidate the relationship between certain fossil faunas (mostly goniatites, lamellibranchs and brachiopods) and the petrology of the enclosing sediment. Hence, the session as a whole had an emphasis on molluses, particularly cephalopods. Although unplanned, this bias came as a natural sequel to the molluscan theme of Prof. Yonge's presidential address.

Many 'palæoecological' publications (including some by the present author), are merely records of association and distribution, and offer little interpretation of the relationship between the fauna and the environment. The appreciation of $a$ fossil biological system demands not only the reconstruction of the animals themselves but also of how they lived, what they did, their effects on other animals and on the environment. The Norwich session served well to illustrate this palæobiological approach to palæoecology.

In surveying the problems of buoyancy control, Dr. Joysey noted that the majority of living cephalopods are more dense than sea-water and support themselves by swimming, but Sepia, Spirula and Nautilus have a density near that of sea-water, owing to gas enclosed in rigid-walled chambers. Unlike the swim-bladder of a fish, the volume of the cephalopod float is not affected by changes in pressure. Hence, so long as some mechanism prevents the hydrostatic pressure from forcing liquid into the chambers through the porous siphuncular tube, changes in depth should not affect the buoyancy. Denton and Gilpin-Brown have recently shown that Sepia can adjust its buoyancy by pumping liquid in and out of the chambers, like a submarine altering ballast. This liquid has a lower salt concentration than the body fluids, and so osmotic pressure helps to counteract hydrostatic pressure. Dr. Joysey observed that as Spirula and possibly Nautilus are recorded from depths below that at which an osmotic mechanism would fail, some other mechanism must be sought if the gas is to be maintained in the chambers. An increase in the gas pressure would prevent liquid from flowing into the chambers and also prevent implosion of the shell, but any other mechanism whereby the siphuncular tube might become temporarily impermeable to liquid must be accompanied by a shell sufficiently strong to withstand the external pressure.

Dr. Bidder showed some photographs of Nautilus in a state of nearly neutral buoyaney swimming in mid-water or resting on the bottom, and others of it floating with part of the shell breaking the surface of the water. She had also observed under-buoyant animals hanging by their tentacles, and had found that individual specimens could adjust their buoyancy.

Dr. Bidder stated that the gas in the chambers was not under pressure in a specimen just hauled from a depth of nearly 200 metres. She had also extracted quantities of liquid from the gas chambers of Nautilus and using X-ray photographs she demonstrated that when a specimen had been turned upside down the shadows which were presumed to be bodies of liquid had indeed run to the opposite side of the chambers. She found no evidence of living tissue in the gas chambers of Nautilus.

In reviewing present-day interpretations of the posture of various fossil cephalopods, Dr. Joysey noted that the position of the gas chambers in orthoconic shells at first sight suggested that they hovered vertically in the water, or rested on the sea-floor like church steeples. Alternatively, if a load were present at the apical end, such as liquid in the apical chambers, they could have adopted a horizontal posture. It is generally accepted that, in some forms, this apical counterbalance was provided by solid deposits within the siphuncular tube. Other forms have deposits within the apical gas chambers, but there has been some controversy as to whether these were laid down by a cameral mantle or whether they are postmortem mineral infillings. In view of the recent findings on living forms, Dr. Joysey suggested that serious consideration should be given to the possibility that these deposits might have been precipitated during life from solutions transported through the walls of the siphuncular tube.

By analogy with orthoconic nautiloids, Dr. Joysey pointed out that one of the functions of the belemnite 
guard was to act as a counterbalance. It lay at the posterior end of the main gas chambers while the bulk of the animal was at the anterior end, so giving a 'see-saw' type of stability. The morphological series from the belemnite to Sepia is well known. Functionally, this change involved sliding the body mass under the gas chambers, giving an 'air-ship' type of stability. In consequence, the counterbalance was progressively reduced and hence the volume of gas required to provide support could also be reduced.

Dr. Joysey referred to some palæozoic nautiloids (for example, Ascoceras) in which the juvenile was orthoconic, but by the development of highly oblique septa the adult achioved a horizontal posture, without resort to a counterbalance. Coiling of the shell produces a similar result as the body chamber comes to lie more or less horizontally below the float. Dr. Joysey briefly described Trueman's elegant investigation on the buoyancy and posture of ammonites. Trueman showed that an uncoiled form such as Lytocrioceras possessed greater stability than its tightly coiled counterpart. In functional terms such a shell has achieved the 'air-ship' type of stability, independently attained in such distantly related forms as Ascoceras and Sepia.

Dr. Bidder stated that Nautilus appears somewhat clumsy in side view but when seen from above, below or behind, its outline is remarkably streamlined. Its movement is slow in the encumbered environment of the aquarium, but more rapid in open water. Although it frequently swam near the bottom of the aquarium with its tentacles 'searching' the substratum, it had never been observed to crawl. Some of the photographs clearly showed the remark. able flexibility of the tip of the funnel, which can send the jet in almost any direction, thus giving considerable mancuvrability.

Dr. Bidder stated that the density of the body of Nautilus appears to be somowhat lower than Trueman's calculated value, and she suggested that it might prove necessary to modify his conclusion that the majority of ammonites were under-buoyant. Furthermore, his interpretations of the posture of ammonites are amenable to modification if the chambers contained unequally distributed fluid ballast.

Dr. Broadhurst outlined the work of Dr. J. G. Potts on the Gastrioceras cancellatum marine band near the top of the Millstone Grit Series, the work of Mr. R. W. Sheldon on another marine band in the Edale Shales towards the base of the Millstone Grit, and his own work in the Coal Measures.

In Dr. Pott's marine band some of the goniatites are preserved flat on their sides, whereas others are crushed in a vertical position, just as they settled on the sea-floor, leaving impressions of the venter on the bedding planes. It was suggested that a high proportion of vertically preserved goniatites probably indicated quiet conditions, and this was found to be at a maximum near the middle of the band, where the goniatites themselves were most abundant. The lamellibranchs had two periods of abundance, one above and the other below the goniatite maximum. The grain size and the amount of coarse detritus both had high values at the top and the bottom of the band, prior to the first and after the second lamellibranch peak. The marine band as a whole was described as a 'palæontological sandwich', the goniatites being the filling, the lamellibranchs the butter, and the coarse detritus the bread. It appeared that the absence of fauna in the sediments above and below the marine band could be attributed to turbulence and the greater rate of terrigenous sedimenta. tion.

Mr. Sheldon's band contained fewer goniatites and lamellibranchs but abundant brachiopods. The amount of detrital material was low, most of the sediment being ankerite and silica. The brachiopods Chonetes and Martinia, the goniatite Eumorphoceras and the gasteropods in the fauna were abundant in the upper and lower parts of the band and sparse in the middle, analogous in pattern to the lamellibranch distribution present in Dr. Pott's marine band. In contrast the brachiopod Productus was abundant near the middle of the band and diminished upwards and downwards, this pattern corresponding with the abundance of ankerite.

Dr. Broadhurst was largely concerned with the conditions of sedimentation between marine bands. He showed photographs of a tree-cast $38 \mathrm{ft}$. high, standing vertically in non-marine sediments, its base rooted above a coal seam and its top in mudstone. He stressed that vertical preservation is not to be regarded as a freak occurrence, for he has records of many such trees at several horizons. Such preservation can only be interpreted as indicative of rapid sedimentation and it is significant in this respect that these vertical trees never cut through marine bands. Viewing their work as a whole Dr. Broadhurst suggested that a slow rate of deposition of terrigenous material appears to have been an important controlling factor during the deposition of the relatively thin marine bands, whereas more rapid sedimentation appears to have characterized the thicker intervening beds.

In the discussion which followed the papers Dr. Broadhurst and his colleagues indicated that the onset and the ending of marine band conditions were transitional rather than abrupt. Lateral changes could be detected at some horizons, for some Lingula beds pass laterally into true marine bands in other regions.

Dr. Joysey agreed that partially uncoiled ammonites like Lytocrioceras must have adopted different postures at various stages during growth, and commented that these might reflect changes in its feeding requirements. He noted that it was widely stated in the palæontological literature that Nautilus could adjust its buoyancy by moving in or out of its shell. Changes in shape of the body mass, however, would not affect its volume and so the density of the body would remain constant. Assuming that any space vacated within the body chamber would be filled with sea-water, then movements of the body would not affect its overall density. It appeared to him that this mechanism could not produce changes in density unless there was an unsealed gas bubble within the body chamber. Dr. Bidder stated that there was no gas bubble between the animal and the last septum, and that although small bubbles were sometimes present in the mantle cavity, these could be attributed to the aquarium aeration system.

The session as a whole provided useful liaison between geologist and zoologist, and each was able to gain a greater appreciation of some of the practical difficulties faced by the other in obtaining sufficient. information to give an unequivocal answer to an apparently simple question. It also served to illustrate that one class of animals alone could provide abundant material for discussion, and that there remained plenty of scope for future joint sessions.

K. A. JoYSEY 